\title{
Biochemical and Haematological Studies on the Ethanol Leaf Extract of Spondias mombin Linn
}

\author{
Igwe CU*, Onwuliri VA, Osuagwu CG, Onyeze GOC and Ojiako OA \\ Department of Biochemistry, Federal University of Technology, Owerri, Nigeria
}

\begin{abstract}
Spondias mombin Linn (Anacardiaceae) is an edible plant that is ethnopharmacologically used for induction of labour, expulsion of afterbirth, and stabilization of women after childbirth. The effects of ethanol extract of the leaf of $S$. mombin on hepatic, renal and haematologic function indices of albino rabbits were studied using standard methods. Acute toxicity studies of the extract showed the lethal dose $\left(\operatorname{LD}_{50}\right)$ to be indeterminate, while the effective (abortifacient) dose $\left(E D_{50}\right)$ was $753.96 \pm 0.10 \mathrm{mg} / \mathrm{kg}$ body weight. Intraperitoneal administration of $750 \mathrm{mg} / \mathrm{kg}$ body weight of the extract significantly $(p<0.05)$ reduced serum alanine aminotransferase and aspartate aminotransferase activities, as well as the serum concentrations of total bilirubin, urea and creatinine, but increased the serum concentrations of total protein, albumin and haemoglobin, as well as the values of white blood cell count, platelet count, and the calculated red cell indices. The results of the study showed that the extract does not have detrimental toxicological effects on the studied organs/tissue function indices. However, it's observed effect on platelet count calls for further studies.
\end{abstract}

Keywords: Hog plum; Liver; Kidney; Haematologic indices; Electrolytes

\section{Introduction}

Spondias mombin is a common flowering plant that is commonly called hog plum. Locally in Nigeria, it is known as akika in Yoruba, ijikara in Igbo and tsadar masar in Hausa [1]. The plant leaves are common animal forage. The tender leaves and ripe fruits are also edible. The bark leaves and fruit juice have been widely used for varied folk medical purposes [2]. Preliminary researches reported the plant to have a wide range of antibacterial, antiviral and antifungal properties $[3,4]$. Reports on the plant have been interesting, yet controversial. It was reported to have abortifacient and uterine muscle contraction effects [5,6]. On the other hand, Kramer et al. [7] recommended its use for pregnant woman but only after five months of pregnancy. They noted that the observed cytotoxic effects of the plant may have some benefits in protecting the foetus from pathogens. Furthermore, they claimed that its high level of cytotoxicity, is indicative of analgesic properties. Thus they concluded that the use of the plant to ease pain during childbirth supports this evidence [7]. In the same vein, it was earlier observed [8] that the infusion of S. mombin leaves is variously used, without any reported collateral effects due to its activity. However, apart from the abortifacient effect noted above, Raji et al. [9] showed that the aqueous leaf extract of the plant has a dose-dependent antifertility action, but with full recovery achieved within four weeks after cessation of treatment with the extract.

Given the varied ethnomedicinal uses of the plant, the alleged noncollateral effects when ingested and the reported possible anti-fertility and abortifacient effects, the present study was designed to assess the safety of $S$. mombin leaves using the hepatic, renal and haematologic function indices of albino rabbits.

\section{Materials and Methods}

\section{Plant material}

Leaves of Spondias mombin were obtained from the bushes in Obinze and Iheagwa villages in Owerri West Local Government Area of Imo State. The leaves were duly authenticated at the Department of Crop Science, Federal University of Technology, Owerri. Voucher specimen was deposited in the departmental herbarium.

\section{Preparation of plant material}

The leaves of $S$. mombin were plucked from the stem stalks, rinsed in clean water and air-dried at room temperature. The dried leaves were ground into fine powder with a mechanical grinder (Heman, Japan). About $1.4 \mathrm{~kg}$ of the powdered leaf was soaked in $3.5 \mathrm{~L}$ of $75 \%$ ethanol in a $5 \mathrm{~L}$ beaker and covered with aluminum foil. The mixture was stirred every 3 hours for proper mixing and allowed to stand for 24 hours. The resulting decoction was filtered and the filtrate was subjected to a slow but complete solvent evaporation using a regulatory hot plate (Techmel, USA) at a temperature of $40-60^{\circ} \mathrm{C}$. The extract was packaged in an air-tight container, labeled and stored below $4^{\circ} \mathrm{C}$ in a freezer until required [10].

\section{Acute toxicity Tests}

Lethal dose $\left(\mathrm{LD}_{50}\right)$ determination: The lethality of the $S$. mombin leaf extract was estimated using 36 healthy female albino mice divided into 6 groups with 6 mice each group. Each group received a dose of extract (ranging from 500-3000 mg/kg in $1 \mathrm{ml}$ of normal saline) intraperitoneally. The number of deaths in each group within 24 hours was recorded. The $\mathrm{LD}_{50}$ was then estimated from the graph of percentage mortality (converted to probit) against log-dose of the extract using the probit method of Miller and Tainter [11].

Effective Abortion dose $\left(\mathrm{ED}_{50}\right)$ determination: Thirty-six pregnant mice at about the 15th day (third trimester) of pregnancy were used for the study. The animals weighing between 15 and 30 $\mathrm{g}$ were divided into six groups with six animals in each group. They

*Corresponding author: Igwe CU, Department of Biochemistry, Federal University of Technology, Owerri, Nigeria, Tel: +234-8066-075-587; E-mail: igwechidi@yahoo. com

Received September 29, 2011; Accepted December 13, 2011; Published December 14, 2011

Citation: Igwe CU, Onwuliri VA, Osuagwu CG, Onyeze GOC, Ojiako OA (2011) Biochemical and Haematological Studies on the Ethanol Leaf Extract of Spondias mombin Linn. Biochem \& Anal Biochem 1:104. doi:10.4172/2161-1009.1000104

Copyright: @ 2011 Igwe CU, et al. This is an open-access article distributed under the terms of the Creative Commons Attribution License, which permits unrestricted use, distribution, and reproduction in any medium, provided the original author and source are credited. 
were treated with increasing doses of the ethanol extract ranging from 250 to $1500 \mathrm{mg} / \mathrm{kg}$, administered intraperitoneally as a single dose in $1 \mathrm{ml}$ of normal saline. All the animals were allowed access to feed (Guinea Feed Nigeria $\operatorname{Ltd}^{\mathrm{TM}}$ ) and water ad libitum, and observed for treatment related abnormalities. These included foetal abortion and presence of vaginal bleeding for a period of 24 hours. They were further observed for general behavior for extra 7 days. The number of animals that aborted within the first 24 hours was noted for each group and subsequently $\mathrm{ED}_{50}$ was calculated by the graphical probit method of Miller and Tainter [11]. The $\mathrm{ED}_{50}$ was determined as a guide for dosage level to use for the biochemical and haematological effects study.

Animal grouping for Biochemical and Haematological Studies: Thirty-five female albino rabbits $(1.47 \pm 0.17 \mathrm{~kg})$ were obtained locally from Owerri, Imo State. The animals were housed in stainlesss steel cages under standard laboratory condition of 12 hours light/dark cycle. They were allowed access to feed (Guinea Feed Nigeria Ltd) and water ad libitum and allowed to acclimatize for 7 days before grouping and treatment.

The thirty-five rabbits were randomly divided into 7 groups with 5 rabbits in each group as follows:

Group 1 - the baseline control that were not administered any drug and were sacrificed on the zero day.

Group 2 - administered normal saline per kg and served as control for the 7 days treatment.

Group 3 - administered $0.14 \mathrm{IU} / \mathrm{kg}$ of standard oxytocin drug (Pitocin ${ }^{\circ}$, USA) for 7 days.

Group 4 - administered $750 \mathrm{mg} / \mathrm{kg}$ of $S$. mombin extract for 7 days.

Group 5 - administered normal saline per kg and served as control for the 14 days treatment.

Group 6 - administered $1 \mathrm{ml}$ ( $0.14 \mathrm{IU} / \mathrm{kg}$ body weight) of standard oxytocin drug (Pitocin ${ }^{\circledR}$, USA) for 14 days.

Group 7 - administered $750 \mathrm{mg} / \mathrm{kg}$ of S. mombin extract for 14 days.

The animals were administered $1 \mathrm{ml}$ of their respective drugs/ extracts reconstituted in normal saline, intraperitoneally, once daily for their stipulated peroid.

\section{Sample collection}

At the end of each experimental period, 5 fasting animals were randomly selected from each group, anaesthetized with chloroform, and about $20 \mathrm{ml}$ of blood collected by cardiac puncture from each animal. The blood sample was dispensed, $5 \mathrm{ml}$ each, into an EDTA bottle, a lithium heparin bottle and a non-anticoagulant containing (plain) bottle. The sample in the EDTA bottle was mixed thoroughly and used for hematological studies. The blood sample in the heparin container was centrifuged (Teco, USA) at $4000 \mathrm{rpm}$ for $5 \mathrm{~min}$ to obtain the plasma which was stored frozen until used for the determination of extracellular cations concentrations, while the packed red cells were washed thrice with normal saline, drained dry and lysed with $1 \mathrm{ml}$ of distilled water and stored frozen until used for the determination of intracellular cations concentrations. The sample in the plain container was allowed to stand for $30 \mathrm{~min}$ to clot, and then centrifuged at 4000 rpm for $5 \mathrm{~min}$. The serum was carefully separated into another sterile plain bottle and stored frozen until used for the analysis for liver and kidney function indices [11].

\section{Liver function indices}

The serum activities of alanine aminotransferase (ALT; EC 2.6.1.1), aspartate aminotransferase (AST; EC 2.6.1.2) and alkaline phosphatase (ALP; EC 3.1.3.1), as well as the serum concentrations of total bilirubin, conjugated bilirubin, total protein and albumin were determined [12] using standard kits (Human Laboratories, Germany). The unconjugated bilirubin concentration was calculated as the difference between total and conjugated bilirubin concentrations.

\section{Kidney function and electrolyte indices}

Serum urea and creatinine concentrations were determined by Jaffe's reaction and urease enzymatic method respectively [13], using standard kits (Human Laboratories, Germany). Serum bicarbonate (as total $\mathrm{CO}_{2}$ ) concentration was determined by the use of a $\mathrm{CO}_{2}$ gas electrode (ASTRA $\mathrm{CO}_{2}$ apparatus, Beckman Instruments, USA), while chloride concentration was determined by the titrimetric method of Schales and Schales [13]. Serum (extracellular) and erythrocytic (intracellular) sodium, potassium, calcium and magnesium concentrations were determined by use of an atomic absorption spectrophotometer (Alpha 4, Chem. Tech. Analytical, England).

\section{Haematological indices}

The haematological indices involving packed cell volume (PCV), haemoglobin $(\mathrm{Hb})$ concentration, white blood cell (WBC) count, platelet count and the red blood cell indices including mean corpuscular volume $(\mathrm{MCV})$, mean corpuscular haemoglobin $(\mathrm{MCH})$ and mean corpuscular haemoglobin concentration $(\mathrm{MCHC})$ were determined using an automated haematology analyzer machine (Mindray BC 2300, USA) which performs blood cell count by Direct Current detection method, haemoglobin analysis by non-cyanide haemoglobin analysis method and calculates the red blood cell constants automatically from red blood cell count, $\mathrm{Hb}$ and $\mathrm{PCV}$.

\section{Statistical analysis}

Data generated were analyzed by the use of one-way ANOVA and Bonferroni's multiple comparison tests, with the aid of a computerbased statistical package (Graphpad Prism 5.3). Inferences were made at $95 \%$ confidence level.

\section{Results}

\section{Yield of ethanol extract of dry leaves of S. mombin}

One kilogram weight of dry leaves of S. mombin yielded $27.71 \mathrm{~g}$ (1.98\%) of crude ethanol extract.

\section{Acute toxicity studies}

The results of the acute toxicity studies showed the $\mathrm{LD}_{50}$ to be indeterminate because no animal died within the period of study, while the abortion $\mathrm{ED}_{50}$ in pregnant mice was $753.96 \pm 0.10 \mathrm{mg} / \mathrm{kg}$ body weight.

\section{Effect of spondias mombin leaf extract on liver function indices}

Administration of $S$. mombin extract and oxytocin drug significantly $(\mathrm{P}<0.05)$ reduced serum ALT and AST activities at both the 7 th and 14th days of treatment (Table 1). Serum ALP activity was, on the other hand, significantly $(\mathrm{p}<0.05)$ increased by the extract, only after 14 days of administration from a baseline value of 64.08 $\pm 3.60 \mathrm{IU} / 1$ to $103.09 \pm 11.05 \mathrm{IU} / \mathrm{l}$. The extract administration non- 
Citation: Igwe CU, Onwuliri VA, Osuagwu CG, Onyeze GOC, Ojiako OA (2011) Biochemical and Haematological Studies on the Ethanol Leaf Extract of Spondias mombin Linn. Biochem \& Anal Biochem 1:104. doi:10.4172/2161-1009.1000104

Page 3 of 5

\begin{tabular}{|c|c|c|c|c|c|c|c|}
\hline \multirow[b]{2}{*}{ Indices } & \multirow{2}{*}{\begin{tabular}{|l} 
Day 0 \\
Baseline
\end{tabular}} & \multicolumn{3}{|c|}{ Day 7} & \multicolumn{3}{|c|}{ Day 14} \\
\hline & & Control & Oxytocin & Extract & Control & Oxytocin & Extract \\
\hline Alanine Aminotransferase (IU/I) & $26.41 \pm 2.52^{\mathrm{a}}$ & $26.70 \pm 2.21^{\mathrm{a}}$ & $15.15 \pm 2.92^{b}$ & $17.89 \pm 1.08^{b}$ & $28.82 \pm 2.20^{\mathrm{a}}$ & $18.09 \pm 1.01^{b}$ & $19.81 \pm 1.75^{b}$ \\
\hline Aspartate Aminotransferase (IU/I) & $43.27 \pm 1.56^{\mathrm{a}}$ & $43.42 \pm 0.48^{a}$ & $17.43 \pm 1.32^{\mathrm{b}}$ & $13.64 \pm 1.38^{c}$ & $42.24 \pm 2.17^{a}$ & $14.19 \pm 0.82^{c}$ & $16.47 \pm 0.87^{\mathrm{b}}$ \\
\hline Alkaline Phosphatase (IU/I) & $64.08 \pm 3.60^{\mathrm{a}}$ & $67.72 \pm 3.87^{a}$ & $75.48 \pm 2.52^{a}$ & $64.83 \pm 7.49^{a}$ & $65.16 \pm 2.19^{a}$ & $68.40 \pm 4.45^{\mathrm{a}}$ & $103.09 \pm 11.05^{b}$ \\
\hline Total bilirubin $(\mu \mathrm{mol} / \mathrm{l})$ & $5.51 \pm 1.51^{\mathrm{a}}$ & $5.54 \pm 1.53^{a}$ & $5.36 \pm 0.71^{a}$ & $4.90 \pm 0.20^{a}$ & $5.40 \pm 0.12^{\mathrm{a}}$ & $6.94 \pm 0.68^{a}$ & $4.61 \pm 0.86^{a}$ \\
\hline Conjugated bilirubin $(\mu \mathrm{mol} / \mathrm{l})$ & $1.98 \pm 0.22^{\mathrm{a}}$ & $2.06 \pm 0.27^{\mathrm{a}}$ & $2.45 \pm 0.31^{\mathrm{a}}$ & $2.22 \pm 0.34^{\mathrm{a}}$ & $1.95 \pm 0.15^{a}$ & $2.25 \pm 0.09^{a}$ & $1.98 \pm 0.22^{\mathrm{a}}$ \\
\hline Unconjugated bilirubin $(\mu \mathrm{mol} / \mathrm{l})$ & $3.53 \pm 0.86^{\mathrm{a}}$ & $3.48 \pm 1.46^{\mathrm{a}}$ & $3.91 \pm 0.66^{a}$ & $2.69 \pm 0.40^{\mathrm{a}}$ & $3.45 \pm 0.06^{\mathrm{a}}$ & $4.69 \pm 0.65^{b}$ & $2.63 \pm 0.80^{\mathrm{a}}$ \\
\hline Total protein $(\mathrm{g} / \mathrm{l})$ & $61.33 \pm 1.89^{\mathrm{ab}}$ & $62.14 \pm 4.23^{a}$ & $52.56 \pm 3.22^{b}$ & $66.43 \pm 3.58^{\mathrm{a}}$ & $67.51 \pm 3.50^{\mathrm{a}}$ & $57.06 \pm 3.41^{b}$ & $72.49 \pm 3.00^{c}$ \\
\hline Albumin (g/l) & $30.23 \pm 4.12^{\mathrm{a}}$ & $31.99 \pm 4.70^{a}$ & $30.39 \pm 3.56^{a}$ & $47.89 \pm 1.79^{b}$ & $30.64 \pm 1.96^{a}$ & $35.59 \pm 3.85^{a}$ & $53.50 \pm 2.96^{b}$ \\
\hline
\end{tabular}

Values are mean \pm standard deviation (number of animals per group $=5$ ); values with different superscript(s) in a row are significantly different $(p<0.05)$.

Table 1: Effect of ethanol extract of $S$. mombin leaves on liver function indices.

significantly $(\mathrm{p}>0.05)$ reduced serum total and unconjugated bilirubin concentrations. Conversely, the extract significantly $(p<0.05)$ increased serum total protein and albumin concentrations in comparison with their respective baseline values.

\section{Effect of Spondias mombin leaf extract on kidney function and electrolyte indices}

Figure 1 and Table 2 show that the extractadministration significantly $(\mathrm{p}<0.05)$ reduced serum urea and creatinine concentrations, but without significant $(\mathrm{p}>0.05)$ effects on serum chloride and bicarbonate concentration as well as intracellular and extracellular erythrocyte $\mathrm{Na}^{+}$concentration. On the other hand, the extract caused significant $(\mathrm{p}<0.05)$ reductions in the extracellular concentrations of $\mathrm{K}^{+}$and $\mathrm{Ca}^{2+}$, as well as in intracellular $\mathrm{Mg}^{2+}$ concentration, with a concomitant significant $(\mathrm{p}<0.05)$ increase in intracellular $\mathrm{Ca}^{2+}$ concentration.

\section{Effect of Spondias mombin leaf extract on haematological indices}

Administration of both $S$. mombin extract and oxytocin did not significantly $(p>0.05)$ alter packed cell volume, mean corpuscular haemoglobin and mean corpuscular haemoglobin concentration values of the treated animals in comparison with those of the controls. However, treatment with the extract for up to 14 days significantly $(p<0.05)$ increased mean corpuscular haemoglobin concentration (Figures 2,3). Both the extract and oxytocin administrations significantly $(\mathrm{p}<0.05)$ increased the white blood cells and platelet counts of the treated animals (Figure 4).

\section{Discussion}

\section{Acute toxicity effect of Spondias mombin leaf extract}

The results of the acute toxicity study showed an indeterminate $\mathrm{LD}_{50}$, even at $3 \mathrm{~g} / \mathrm{kg}$ extract administration. The animals, especially those on higher doses of the extract showed reduced agility and were occasionally clustered together at one corner of their cages. This is in corroboration with earlier findings [14] that, apart from occasional clustering of the rats, acute toxicity test with up to $2 \mathrm{~g} / \mathrm{kg}$ of ethanol leaf extract of S. mombin showed no lethal effect.

The abortion $\mathrm{ED}_{50}$ in the pregnant mice was found to be $753.96 \pm$ $0.10 \mathrm{mg} / \mathrm{kg}$. The result is in consonance with an earlier report of $750 \pm$ $20 \mathrm{mg} / \mathrm{kg}$ [5].

\section{Effect of Spondias mombin leaf extract on liver function} indices

The reductions in alanine and aspartate aminotransferases (ALT and AST) activities observed following administration of S. mombin leaf extract may be attributed to reduced rate of synthesis of the liver enzyme as a consequence of extract exposure. Administration of the extract for up to 14 days did not further depreciate the enzymes activities in comparison with activities noted at the 7th day, indicating an adaptation by the liver cells to the assault from the plant extract.

On the other hand, the initial 7 days administration of the extract did not affect serum alkaline phosphatase (ALP) activity, another marker enzyme employed to assess the integrity of hepatic plasma membrane. However, further administration for up to 14 days increased significantly ALP activity. The later increase in ALP activity observed may be due to enzyme induction by the extract [15] The increased ALP activity may be attributed to the effects of some divalent ions such as $\mathrm{Mg}^{2+}$ and $\mathrm{Zn}^{2+}$ which are established activators of ALP and are reported to be present in the leaves [16]. This inference could further be buttressed by the observed overall reduction in the concentrations of total and unconjugated bilirubin, indicating that the xenobiotic conjugative and excretive potentials of the organ were not affected by the administration of the extract. Furthermore, the extract elicited time-dependent increases in serum total protein and albumin concentrations. The liver is the sole site for synthesis of albumin, which makes up approximately $60 \%$ of serum protein concentration. The observed increases in total protein and albumin concentrations with administration of the extract indicate that the synthetic function of the hepatocytes were not impaired. The increased synthesis of albumin may also have contributed in the reduction in overall unconjugated bilirubin, since it is the sole transporter of this water insoluble byproduct of haemoglobin metabolism to the liver.

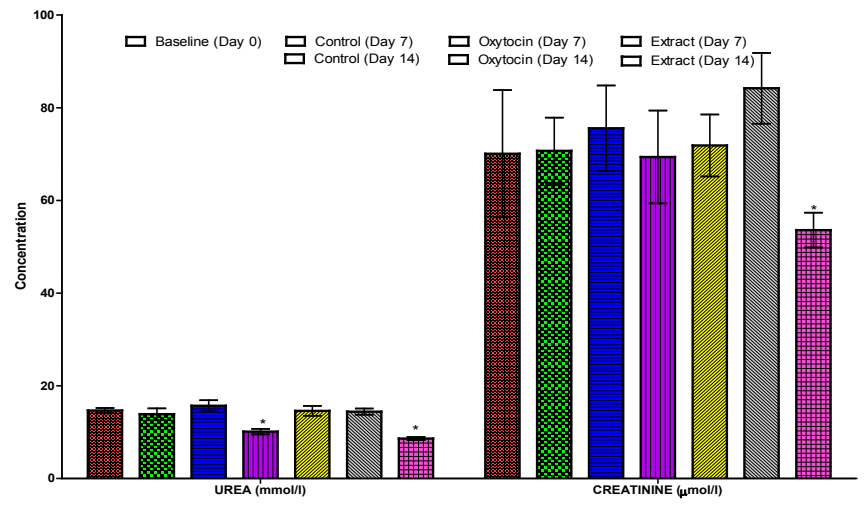

*Values significantly $(p<0.05)$ reduced in comparison with their respective baseline (Day 0) values.

Figure 1: Effect of ethanol extract of Spondias mombin leaves on serum urea and creatinine concentrations. 


\begin{tabular}{|c|c|c|c|c|c|c|c|}
\hline \multirow[b]{2}{*}{ Indices } & \multirow{2}{*}{$\begin{array}{c}\text { Day } 0 \\
\text { Baseline }\end{array}$} & \multicolumn{3}{|c|}{ Day 7} & \multicolumn{3}{|c|}{ Day 14} \\
\hline & & Control & Oxytocin & Extract & Control & Oxytocin & Extract \\
\hline Chloride $(\mathrm{mmol} / \mathrm{l})$ & $107.00 \pm 7.58^{a}$ & $105.89 \pm 8.75^{\mathrm{a}}$ & $112.01 \pm 8.92^{\mathrm{a}}$ & $114.60 \pm 9.07^{a}$ & $109.90 \pm 11.19^{\mathrm{a}}$ & $111.21 \pm 13.07^{a}$ & $117.00 \pm 9.72^{a}$ \\
\hline Bicarbonate $(\mathrm{mmol} / \mathrm{l})$ & $19.65 \pm 1.67^{\mathrm{a}}$ & $20.02 \pm 2.51^{a}$ & $17.54 \pm 1.62^{\mathrm{a}}$ & $18.94 \pm 1.93^{a}$ & $19.50 \pm 1.69^{a}$ & $19.60 \pm 2.32^{a}$ & $18.78 \pm 1.64^{\mathrm{a}}$ \\
\hline Extracellular $\mathrm{Na}^{+}(\mathrm{mmol} / \mathrm{l})$ & $125.80 \pm 4.82^{\mathrm{a}}$ & $126.78 \pm 13.56^{a}$ & $121.20 \pm 5.26^{a}$ & $135.60 \pm 6.15^{a}$ & $126.00 \pm 5.43^{a}$ & $125.40 \pm 7.13^{a}$ & $138.60 \pm 4.10^{a}$ \\
\hline Intracellular $\mathrm{Na}^{+}(\mathrm{mmol} / \mathrm{l})$ & $5.91 \pm 1.20^{\mathrm{a}}$ & $5.62 \pm 0.82^{\mathrm{a}}$ & $4.81 \pm 0.89^{a}$ & $5.28 \pm 0.91^{\mathrm{a}}$ & $6.06 \pm 1.36^{a}$ & $4.86 \pm 0.41^{\mathrm{a}}$ & $5.56 \pm 0.74^{a}$ \\
\hline Extracellular $\mathrm{K}^{+}(\mathrm{mmol} / \mathrm{l})$ & $6.47 \pm 0.64^{\mathrm{a}}$ & $6.74 \pm 0.69^{a}$ & $6.10 \pm 1.02^{\mathrm{ab}}$ & $5.26 \pm 0.40^{b}$ & $6.86 \pm 0.69^{a}$ & $5.96 \pm 0.67^{a}$ & $5.48 \pm 0.37^{a}$ \\
\hline Intracellular $\mathrm{K}^{+}(\mathrm{mmol} / \mathrm{l})$ & $26.30 \pm 4.72^{\mathrm{abc}}$ & $26.20 \pm 5.29^{\mathrm{abc}}$ & $18.83 \pm 2.65^{\mathrm{ac}}$ & $27.85 \pm 5.70^{b}$ & $27.04 \pm 2.94^{\mathrm{ab}}$ & $18.30 \pm 1.16^{c}$ & $26.65 \pm 4.14^{\mathrm{abc}}$ \\
\hline Extracellular $\mathrm{Ca}^{2+}(\mathrm{mmol} / \mathrm{l})$ & $3.41 \pm 0.91^{\mathrm{ac}}$ & $3.31 \pm 0.75^{\mathrm{ac}}$ & $1.26 \pm 0.28^{b}$ & $1.03 \pm 0.18^{b}$ & $3.70 \pm 0.61^{\mathrm{a}}$ & $2.03 \pm 0.96 b^{c}$ & $1.85 \pm 0.54^{b}$ \\
\hline Intracellular $\mathrm{Ca}^{2+}(\mathrm{mmol} / \mathrm{l})$ & $0.95 \pm 0.10^{\mathrm{a}}$ & $0.86 \pm 0.12^{\mathrm{a}}$ & $4.54 \pm 1.05^{b}$ & $4.63 \pm 1.31^{b}$ & $0.95 \pm 0.07^{\mathrm{a}}$ & $4.27 \pm 0.69^{b}$ & $3.86 \pm 1.04^{b}$ \\
\hline Extracellular $\mathrm{Mg}^{2+}(\mathrm{mmol} / \mathrm{l})$ & $0.90 \pm 0.25^{a}$ & $0.80 \pm 0.14^{\mathrm{a}}$ & $1.70 \pm 0.36^{b}$ & $1.60 \pm 0.33^{a b}$ & $0.85 \pm 0.13^{a}$ & $0.96 \pm 0.24^{a}$ & $1.56 \pm 0.74^{\mathrm{ab}}$ \\
\hline Intracellular $\mathrm{Mg}^{2+}(\mathrm{mmol} / \mathrm{l})$ & $5.10 \pm 0.54^{a}$ & $5.19 \pm 0.86^{a}$ & $3.90 \pm 0.46^{\mathrm{bc}}$ & $3.30 \pm 0.09^{b}$ & $5.05 \pm 0.40^{a}$ & $4.51 \pm 0.72^{a}$ & $3.19 \pm 0.22^{b}$ \\
\hline
\end{tabular}

Values are mean \pm standard deviation (number of animals per group $=5$ ); values with different superscript(s) in a row are significantly different ( $p<0.05$ ).

Table 2: Effect of ethanol extract of $S$. mombin leaves on serum and red blood cell electrolyte indices

It could be inferred that the administration of $S$. mombin leaf extract does not have hepatotoxic effect. The extract is rather hepatoprotective. This inference is corroborated by earlier observations [9] that S. mombin extract administration does not significantly alter liver function parameters. Thus, it may be claimed that the extract may prevent hepatic cell destruction, which is usually marked by an increase in blood aminotransferases activities, increased bilirubin concentration and reduction in serum protein and albumin concentrations [17]. Similarly, administration of the oxytocin standard drug did not cause hepatocellular damage, probably because it is a nona-peptide which is easily metabolized by the liver cells, like other simple exogenous proteins.

\section{Effect of Spondias mombin leaf extract on kidney function and electrolyte indices}

Administration of $S$. mombin extract significantly $(\mathrm{p}<0.05)$ reduced serum urea and creatinine concentrations. This substantiates the reported diuretic potential of the plant in ethnomedical practice [2]. The extract did not significantly $(\mathrm{p}>0.05)$ affect intracellular concentrations of $\mathrm{Na}^{+}$and $\mathrm{K}^{+}$, but increased (non-significantly, $\mathrm{p}>0.05$ ) extracellular $\mathrm{Na}^{+}$with a concomitant time-dependent reduction in $\mathrm{K}^{+}$ extracellular concentration. This also points to the diuretic potential of the extract, given that the extract is a rich source of potassium [16]. On the other hand, the administration of the extract did not significantly ( $p>0.05$ ) affect both chloride and bicarbonate ions concentrations.

Furthermore, the extract caused a significant $(\mathrm{p}<0.05)$ increase in the intracellular $\mathrm{Ca}^{2+}$ concentration, while significantly $(\mathrm{p}<0.05)$ reducing the extracellular $\mathrm{Ca}^{2+}$ concentration. The extract as well as oxytocin standard drug had inverse effects on intracellular and extracellular $\mathrm{Mg}^{2+}$ to those on $\mathrm{Ca}^{2+}$. These inverse effects on intra- and extracellular $\mathrm{Mg}^{2+}$ concentrations by both the extract and oxytocin may be a reflection of the tendency of the body to balance cations level in the intra- and extracellular fluids. Factors that modulate renal $\mathrm{Mg}$ excretion can have profound effects on $\mathrm{Mg}$ balance. Thus, the apparent hypermagnesaemia created by the administration of the extract may lead to increased urinary excretory potential and consequently increased diuresis.

Unlike the extract, oxytocin administration reduced the concentrations of intracellular $\mathrm{K}^{+}$, explaining its action through efflux of $\mathrm{K}^{+}$and influx of $\mathrm{Ca}^{2+}$ into the cell. Meanwhile, the significant $(\mathrm{p}<0.05)$ increase in intracellular $\mathrm{Ca}^{+}$concentration elicited by both the extract and oxytocin indicates activation of the $\mathrm{Ca}^{2+} / \mathrm{K}^{+}$pump which is necessary for the maintenance of the action potential required for initiation of muscle contraction.

\section{Effect of Spondias mombin leaf extract on haematological indices}

This study shows that $S$. mombin extract administration did not significantly increase haemoglobin $(\mathrm{Hb})$ concentration, packed cell volume (PCV), erythrocyte sedimentation rate (ESR), and white blood cell count (WBC) levels of the treated animals. This indicates that the extract does not have a haematoxic effect. This observation is corroborated by the earlier discussed overall reduction in total and unconjugated bilirubin concentrations, which are indicative of non red blood cell-lysing effect of the extract. However, the slight increase in WBC observed after 14 days of extract and oxytocin administrations could be attributed to the response of the immune system to the assault on the animals' system by the drugs' administration. The PCV was not significantly affected by the extract indicating that the amount of red blood cells present in the animals remained fairly constant. Similarly, the extract did not cause a drop in the haemoglobin concentration. Thus, the oxygen-carrying capacity of the blood of the animals was therefore not detrimentally affected by the extract administration. The erythrocyte indices, mean corpuscular haemoglobin $(\mathrm{MCH})$ and mean corpuscular haemoglobin concentration (MCHC) are used to mathematically define the concentration of $\mathrm{Hb}$ within the cell. Extract administration produced an overall non-significant increase in $\mathrm{MCH}$ and $\mathrm{MCHC}$, further supporting the observation that $\mathrm{Hb}$ concentration and hence, the oxygen-transporting potential of the blood of the extract-administered animals were not detrimentally affected. The mean corpuscular volume (MCV) is regarded as the average volume of a single red blood cell. There was a non-significant reduction in the

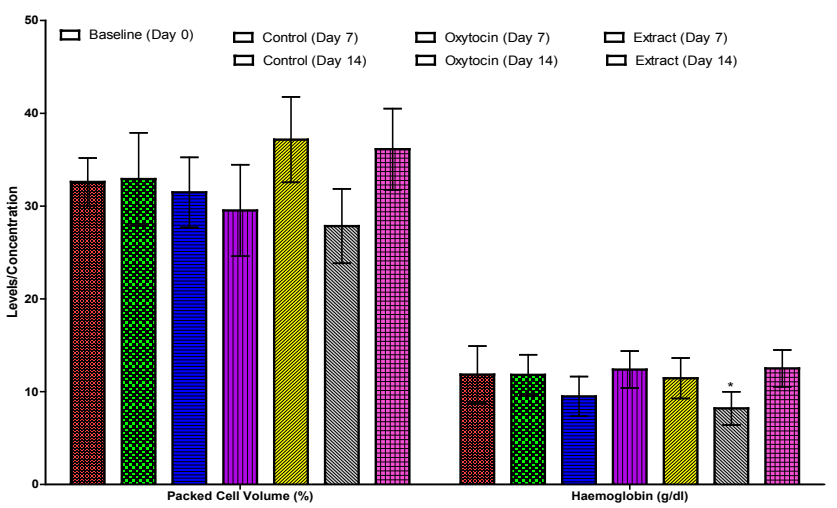

Figure 2: Effect of ethanol extract of Spondias mombin leaves on packed cell volume and haemoglobin concentrations. *Value significantly $(p<0.05)$ reduced in comparison with the respective baseline (Day 0) value. 
Citation: Igwe CU, Onwuliri VA, Osuagwu CG, Onyeze GOC, Ojiako OA (2011) Biochemical and Haematological Studies on the Ethanol Leaf Extract of Spondias mombin Linn. Biochem \& Anal Biochem 1:104. doi:10.4172/2161-1009.1000104

MCV after the first 7 days of extract administration, which however rose non significantly by the 14th day of treatment in comparison with those of the baseline and control values. This later increase may be due to the observed non-significant increase in $\mathrm{Hb}$ content of the red blood cells. These beneficial effects of the extract on the animals' haematological profile, may be attributed to the presence in the plant of flavonoids, vitamin $\mathrm{C}$ and other substances with antioxidant properties $[16,18]$, which may help in red cell membrane stabilization [19], as well as presence of Fe required for $\mathrm{Hb}$ synthesis. The presence of these antioxidant molecules could possibly explain why the red blood cell integrity was generally unaffected by the extract administration.

Interestingly, oxytocin standard drug administration did not have such positive haematologic potentials like the S. mombin extract. Oxytocin administration significantly reduced $\mathrm{Hb}$ concentration and increased WBC count. These effect variations may be because of the absence in this pure standard drug of antioxidant active molecules present in the plant's extract.

On the other hand, both the extract and oxytocin significantly elicited a time-dependent increase in platelet count of the treated animals. Although, the reason for this increase is not presently known, it may not be unrelated to the reported use of the plant for the control of bleeding especially after childbirth [10]. The presence of appreciable

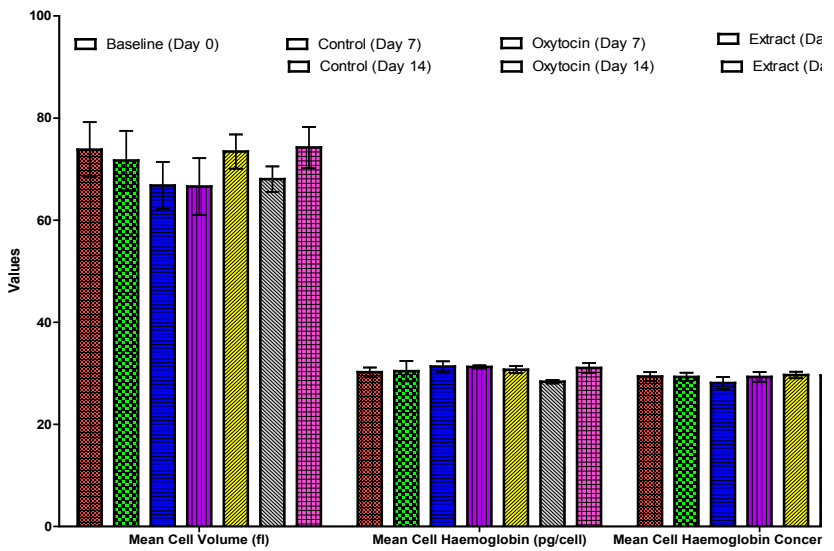

Figure 3: Effect of ethanol extract of Spondias mombin leaves on mean cell volume (MCV), mean cell haemoglobin $(\mathrm{MCH})$ and mean cell haemoglobin concentration $(\mathrm{MCHC})$

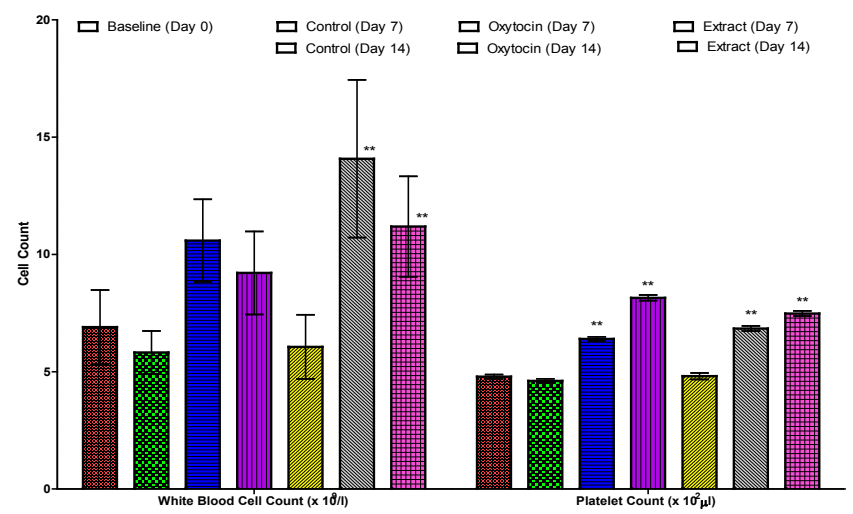

Figure 4: Effect of ethanol extract of Spondias mombin leaves on white blood cell (WBC) and platelet counts. ${ }^{* *}$ Values significantly $(p<0.05)$ increased in comparison with their respective baseline (Day 0 ) values. amounts of vitamin $\mathrm{C}$ in the plant leaves may also contribute immensely to this potential of bleeding control associated with S. mombin [20].

In conclusion, administration of $S$. mombin leaf extract does not have significant toxic effects on liver and kidney cellular functions as well as on the haematological indices of rabbits. Rather, it elicited a dose-dependent increase in serum protein and haemoglobin concentrations, reduction in serum bilirubin concentration, enhanced efflux of $\mathrm{K}^{+}$and influx of $\mathrm{Ca}^{2+}$, and thus a possible activation of cellular cation pumps necessary for initiation of muscle contraction.

\section{References}

1. Gill LS (1992) Ethnomedical uses of Plants in Nigeria. UNIBEN Press, Nigeria

2. Akubue PI, Mittal GC, Aguwa CN (1983) Preliminary Pharmacological Study of some Nigerian Medical Plants. J Ethnopharmacol 8: 53-63.

3. Corthout J, Pieters LA, Claeys M, Vandenberghe DA, Vlietinck AJ (1992) Antiviral caffeoyl esters from Spondias mombin. Phytochem 31: 1979-1981.

4. Corthout J, Pieters LA, Claeys M, Geerts S, Vanden-berghe D, et al. (1994) Antibacterial and molluscicidal phenolic acids from Spondias mombin. Plants Med 60: 460-463.

5. Offiah VN, Anyanwu II (1989) Abortifacient activity of an aqueous extract of Spondias mombin leaves. J Ethnopharmacol 26: 317-320.

6. Nworu CS, Akah PA, Okoli CO, Okoye TC (2007) Oxytocic activity of leaf extract of Spondias mombin. Pharmaceutical Biology 45: 366-371.

7. Kramer A, Mosquera E, Ruiz J, Rodriguez E (2006) Ethnobotany and Biological Activity of Plants utilized during Pregnancy and childbirth in the Peruvian Amazon. Emanations from rain forest and Carribean $4: 31-35$.

8. Corthout J, Pieters LA, Claeys M, Vandenberghe DA, Vlietinck AJ (1991) Antiviral ellagitannins from Spondias mombin. Phytochem 30: 1129-1130.

9. Raji Y, Gbadegesin M, Osonuga A, Adisa RA, Akinsomisoye OS, et al. (2006) Reproductive, Haematologic and Biochemical Profiles of male rats treated with aqueous extract of Spondias mombin bark. Int J Pharmacol 40: 261-267.

10. Igwe CU, Ojiako OA, Nwaogu LA, Onyeze GO (2009) Comparative Effects of Spondias mombin Leaf Extracts on Kidney Function Profile of Rabbits. Res J Agric Biol Sc 5: 1153-1161

11. Wardlaw AC (1985) Practical Statistics for Experimental Biologists. John Wiley \& Sons Ltd, New York.

12. Balistreri WR, Shaw LM (1987) Liver Function: Fundamentals of Clinical Chemistry. (3rd edn), Tietz NW (ed), W.B. Saunders, Philadelphia.

13. Tietz NW (1987) Fundamentals of Clinical Chemistry. (3 $3^{\text {rd }}$ edn), W.B. Saunders, Philadelphia.

14. Uchendu CN, Isek T (2008) Antifertility activity of aqueous ethanolic leaf extract of Spondias mombin (Anacardiaceae) in rats. Afr Health Sci 8: 163-167.

15. Yakubu MT, Adebayo OJ, Egwim EC, Owoyele VB (2005) Increased Liver Alkaline Phosphatase and Aminotransferase Activities following Administration of Ethanolic Extract of Khaya senegalensis Stem Bark to Rats. Biokemisti 17: $27-32$

16. Igwe CU, Onyeze GOC, Onwuliri VA, Osuagwu CG, Ojiako OA (2010) Evaluation of the Chemical Compositions of the leaf of Spondias mombin Linn from Nigeria. Aust J Basic Appl Sci 4: 706-710.

17. Igwe CU, Nwaogu LA, Ujowundu CO (2007) Assessment of the Hepatic effects, Phytochemical and Proximate Compositions of Phyllanthus amarus. Afric $J$ Biotech 6: 728-731.

18. Njoku PC, Akumefula MI (2007) Phytochemical and Nutrient evaluation of Spondais mombin leaves. Pakistan J Nutr 6: 613-615.

19. James O, Nnacheta OP (2008) Comparative Antioxidant Capacity, Membrane Stabilization, Polyphenol Composition and Cytotoxicity of Stem and Leaf Extracts of Cissus multistriata. Afri J Biotechnol 7: 3129-3133.

20. Ayoka AO, Akomolafe RO, Iwalewa EO, Ukponmwan OE (2005) Studies on the anxiolytic effects of Spondias mombin L. (Anacardiacea) extracts. Afr J Trad CAM 2: $153-165$ 